\title{
Mineralogical characterization and evaluation of chromite ore in Grevena and Kozani Vourinos massif, Western Macedonia, Greece
}

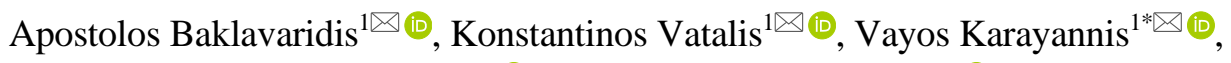 \\ Ploutarchos-Nikolaos Benetis ${ }^{1 \otimes(0)}$, Georgios Charalampides ${ }^{1 \otimes(0)}$ \\ ${ }^{1}$ University of Western Macedonia, Kozani, 50100, Greece \\ *Corresponding author: e-mail vkarayannis@uowm.gr, tel. +302461068022
}

\begin{abstract}
Purpose. Chromite samples from Aetoraches mine area in the southern part of the Vourinos complex in Western Macedonia, Greece were examined from mineralogical-geochemical perspective.

Methods. X-ray Diffraction (XRD) mineral phase analysis, elemental Scanning Electron Microscopy coupled with Energy Dispersive Spectroscopy (SEM-EDS) analysis and Thermogravimetry/Differential Thermogravimetry (TG/DTG) were carried out.

Findings. The XRD results showed that all the samples contain mainly magnesium- and aluminum-chromite ("aluminumpicrochromite") phases, along with forsterite (magnesian olivine), serpentine and chlorite occurrences. Based on the SEMEDS results, the computed average chemical formula indicative of this specific chromite type is: $\left(\mathrm{Fe}_{0.4} \mathrm{Mg}_{0.6}\right)\left(\mathrm{Cr}_{1.6} \mathrm{Al}_{0.4}\right) \mathrm{O}_{4}$. The TG-DTG weight losses found to be in the range of $4.4-14.36 \%$, at temperatures between 600 and $750^{\circ} \mathrm{C}$, indicated the presence of the hydroxyl-rich silicate minerals, serpentinite and chlorite, in agreement to the Loss of Ignition (LOI) results. The mineral phases detected in the present analyses appear in the dunite/diorite/harzburgite/peridotite main rocks of the ophiolitic complex that hosts the chromite ore.

Originality. In the current research, an original characterization, via thorough elemental, phase and thermal analysis, is carried out aiming to enlighten the geochemistry aspects of the Vourinos chromite complex, Region of Western Macedonia, Greece, particularly of easily accessible and exploitable chromite deposits of the Aetoraches mine area.

Practical implications. The chromite mineral, and especially the metallurgical type, is of substantial importance in metal industry. In that sense, the findings of the present investigation of chromite purity and mineral structure is a prerequisite for future exploitation of the Aetoraches chromite deposits in particular and broadly for the ongoing exploitation of chromite ore in the Vourinos complex, situated in Region of Western Macedonia, Greece, an area with high unemployment and rather slow economic growth.
\end{abstract}

Keywords: chromite ore, Vourinos massif, Aetoraches mine area, mineralogical characterization, geochemistry, XRD, SEM-EDS, TG/DTG

\section{Introduction}

Chromite is a mineral that belongs to the spinel group and is found in nature in ultrabasic rocks (dunite, harzsbourgite). The technological classification of chromite ores into categories depends on the $\mathrm{Cr} / \mathrm{Fe}$ ratio and the aluminum content as follows: metallurgical chromite type $\mathrm{Cr} / \mathrm{Fe}>2.8$ :1; refractory chromite type $\mathrm{Cr} / \mathrm{Fe}<2.5: 1$. This mineral, a ferrous and chromium variant of spinel $\left(\mathrm{MgAl}_{2} \mathrm{O}_{4}\right)$ with the general chemical formula $\left(\mathrm{Mg}, \mathrm{Fe}^{+2}\right)\left(\mathrm{Cr}, \mathrm{Al}, \mathrm{Fe}^{+3}\right)_{2} \mathrm{O}_{4}$ constitutes an insignificant phase of basic and ultrabasic rocks and is of petrogenetic significance [1], while the combination with the content of various trace elements in chromatic ores appears to have particular importance for chromitogenesis.
Generally, chemical composition of the chromite is characterized by large variation, mainly in trivalent elements, from $\mathrm{Cr}$ - rich (metallurgical type) to Al- rich (refractory type). Various trace elements, such as elements of the platinum group (Os, lr, Ru, Rh, Pt and Pd), or PGE, Ni, Cu, Co, $\mathrm{V}, \mathrm{Zn}$ and $\mathrm{Ti}$ could likely appear as self-existing minerals (PGM, oxides of Ti) or replace major elements on the chromite lattice. For instance, $\mathrm{V}$ and $\mathrm{Ti}$ replace $\mathrm{Cr}$ and $\mathrm{Al}$ into octahedral positions, while $\mathrm{Mn}, \mathrm{Zn}$ and Co substitute $\mathrm{Mg}$ and $\mathrm{Fe}^{+2}$ into tetrahedral positions of chromite [2], [3].

Some ophiolitic complexes host large deposits of chromite of metallurgical type (i.e. the ophiolite complexes of Vourinos Greece, Bulqiza Albania, the Acoje on Philippines) or only of refractory type (Othrys Greece, Coto in the Philip- 
pines). Other complexes contain the two types of $\mathrm{Cr}$ - and $\mathrm{Al}$ rich chromites (Pindos, Skyros, Rhodope massive in Greece) [4][7]. Important chromite-bearing occurrences in Greece could be found in Halkidiki ( $80 \mathrm{~km}$ long and $10 \mathrm{~km}$ wide), Pieria (Livadi area), Soufli, Veria, Rhodes and finally the Pindos ophiolitic complex.

In the ophiolitic complexes that host a chromite type, the contents of $\mathrm{Ti}, \mathrm{V}, \mathrm{Zn}, \mathrm{Co}$, and $\mathrm{Cu}$ are higher in the refractory type (Othrys) than in the metallurgical one (Vourinos), consistent with the behavior of $\mathrm{Cr}, \mathrm{Al}$ and trace elements during its process of partial melting [8]. Greece could be one of the chromite producing countries with potential exploitable reserves of over 5 million tons with a floating content between 8 and $54 \% \mathrm{Cr}_{2} \mathrm{O}_{3}$. A new promising investment is expected in the wider Kozani-Grevena area of the Western Macedonia Prefecture, for extraction and processing/enrichment of chromite by the mining company Hellenic Mines S.A.

In the current study, a thorough elemental, phase and thermal analysis is carried out, aiming to shed light on the geochemistry and exploitation aspects of the Vourinos complex and especially of the easily accessible and exploitable chromite deposits of the Aetorachi mine area.

\section{Geologic and geotectonic setting}

Most ophiolitic complexes included in the Greek mountain ranges mainly appear in the central and northern section of the country:

a) the series of ophiolites in the western margin of the Pelagonian massif (ophiolitic complexes of Orthis and Pindos mountains), in the Pelagonian mountain range (Vourinos massif) and in the eastern margin of Pelagonian range (Vermio, Veria and EasternThessaly);

b) in the Western Halkidiki (Vavdos, Ormylia Gerakini);

c) in Serbo-Macedonian massif (Gomati, Nigrita) and Rodopi mountain range (Soufli, Exohi Drama) [6].

The geotectonic environment where the ophiolitic complexes are formed is positioned above a submerged plate or as it could be called supra subduction zone, where in most cases an evolution of the geotectonic environment is observed. Most peridotites, accompanied by dunites are in Greece characterized by a relatively strong degree of extraction [2].

Some ophiolitic complexes are known to host exclusively large metallurgical chromite deposits, such as the massifs of Vurinos, Bulgaria, Albania, Acoje in the Philippines, or only refractory type (Othrys Greece, Coto in the Philippines) and others containing the two types of $\mathrm{Cr}$ - and Al-rich chromites, for example Pindos, Skyros, and Rhodope massif [4], [7].

Since the ophiolitic complexes to which Al- and Cr-rich chromite deposits or chromium occurrences are linked with, are characterized by petrological and geochemical characterristics that are consistent with a specific geotectonic environment, the composition of chromite ores is related to the composition of the parent magma and this in turn with the geotectonic environment.

In Region of Western Macedonia, Northern Greece, chromite deposits are observed both in Pindos and Vourinos ophiolite complex. However, Vourinos ophiolites [9] (Fig. 1) are much larger and most exploited [10], [11]. The ophiolitic complex of Vourinos is a Jurassic emplacement (Upper LiasLower Malm) representing alterations of dunite and harzburgite with compact peridotites embedded by mainly pegmatites of gabbro-pyroxenite in the transition zone.

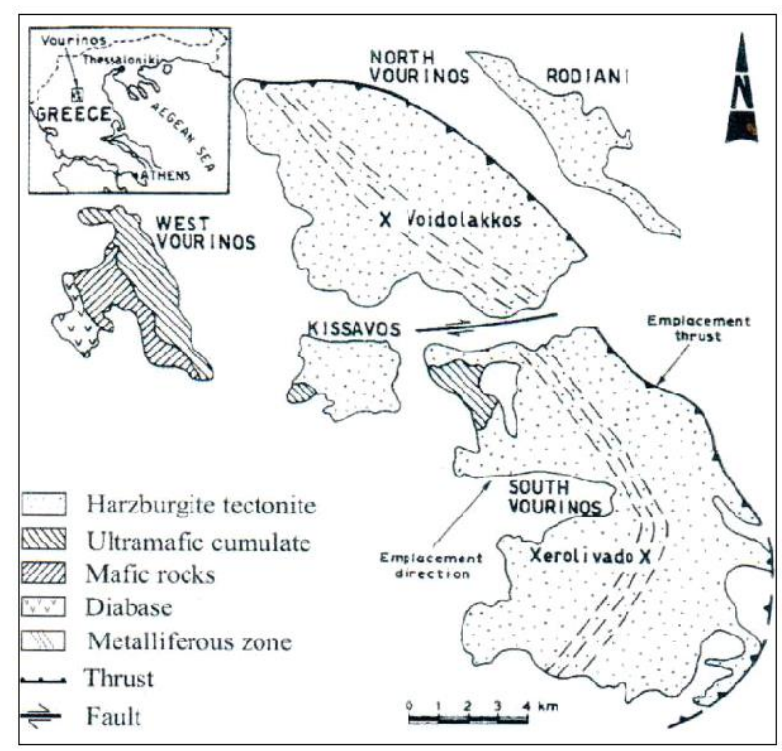

Figure 1. Vourinos ophiolite complex

In particular, this complex represents a mid-Jurassic ophiolitic slab thrusted during upper Jurassic time towards the east over the Pelagonian Margin representing a sedimentarytectonic mélange [12]. A serpentinite alteration zone after dunite and hartzburgite is observed, showing a main direction SE-NW close to Chromium village. In the past, many chromite mines were operating in several localities of Northern, Central and Southern Vourinos district [11] (Fig. 2).

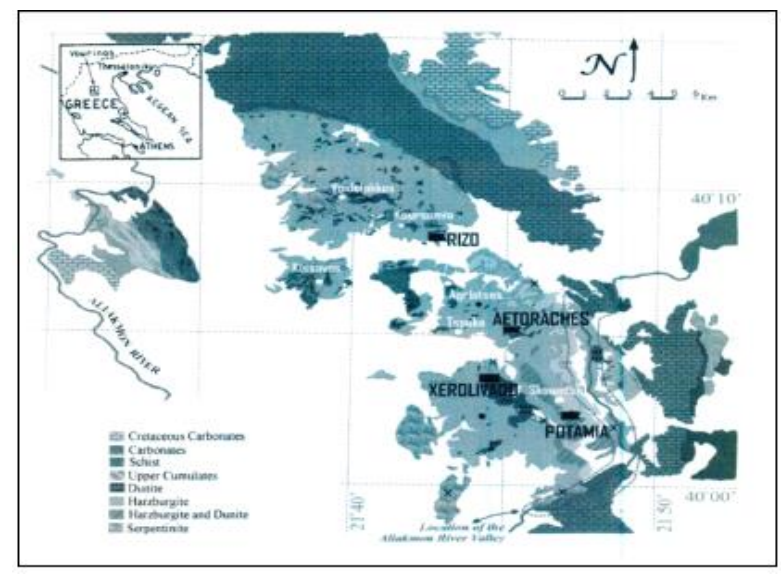

Figure 2. Chromite mines of Vourinos complex

\section{Materials and methods}

\subsection{Sampling}

Various chromatite mines of Vourinos complex were mined in the past. In Table 1, the most significant of those are shown.

All samples characterized in this study were collected from "Aetorache" area in the North of Vourinos complex. Specifically two samples were collected from each site. The GPS coordinates of each site are $40^{\circ} 06^{\prime} 23.6^{\prime \prime}$, $21^{\circ} 43^{\prime} 09.2^{\prime \prime}$ for position $\mathrm{A}$ and $40^{\circ} 06^{\prime} 24.1^{\prime \prime}, 21^{\circ} 43^{\prime} 09.1^{\prime \prime}$ for position $\mathrm{B}$.

In Table 2, sampling areas and sample names are listed while, in Figure 3, photographs of the two sampling positions are shown. 
Table 1. Selected data of main chromatite mines of Vourinos complex mined in the past

\begin{tabular}{|c|c|c|c|c|}
\hline Mine & Location & Reserves & Form & Host \\
\hline $\begin{array}{l}\text { Xerolivado } \\
\text { (Skoumtsa) }\end{array}$ & $\begin{array}{l}\text { Centre of the southern } \\
\text { Vourinos District }\end{array}$ & $\begin{array}{l}\text { The largest ore body in the } \\
\text { complex. Its total reserves are } \\
\text { estimated at about } 3.2 \mathrm{Mt} \text { of } \\
\text { which } 2.2 \mathrm{Mt} \text { has been exploited }\end{array}$ & $\begin{array}{l}\text { Schlieren chromite ores. } \\
\text { Also pods of massive ore } \\
\text { bodies }\end{array}$ & $\begin{array}{l}\text { Hosted by the largest } \\
\text { dunite body within } \\
\text { Vourinos }\end{array}$ \\
\hline Aetorache & $\begin{array}{l}\text { Southern Vourinos } \\
\text { District to the north } \\
\text { of Xerolivado mine }\end{array}$ & A hundred of thousands of tons & $\begin{array}{l}\text { Often massive with minor } \\
\text { schieren and } \\
\text { disseminated ores }\end{array}$ & $\begin{array}{l}\text { Hosted by dunite within } \\
\text { regional harzburgite }\end{array}$ \\
\hline Rizo & $\begin{array}{c}\text { Northern Vourinos } \\
\text { district }\end{array}$ & A hundred of thousands of tons & $\begin{array}{c}\text { Dominantly disseminated } \\
\text { ore with small massive } \\
\text { chromitite lenses }\end{array}$ & $\begin{array}{l}\text { Hosted by dunites - } \\
\text { harzburgites and } \\
\text { serpentinites }\end{array}$ \\
\hline Potamia & $\begin{array}{l}\text { Small mine to the south } \\
\text { of the Xerolivado mine }\end{array}$ & $\begin{array}{l}\text { Reserves are calculated } \\
\text { to just } 30.000 \mathrm{t}\end{array}$ & $\begin{array}{l}\text { Disseminated and } \\
\text { rare schlieren ore }\end{array}$ & $\begin{array}{l}\text { Hosted by dunites - } \\
\text { harzburgites and } \\
\text { serpentinites }\end{array}$ \\
\hline Frourio & $\begin{array}{c}\text { Located in the eastern- } \\
\text { most part of southern } \\
\text { Vourinos }\end{array}$ & Only some thousands tons & $\begin{array}{l}\text { Disseminated ore out } \\
\text { of the metalliferous zone }\end{array}$ & $\begin{array}{l}\text { Hosted by a thin dunite } \\
\text { envelop within } \\
\text { regional harzburgite } \\
\end{array}$ \\
\hline
\end{tabular}

Table 2. Sampling area, positions and sample names

\begin{tabular}{ccc}
\hline Area & Position & Sample name \\
\hline \multirow{3}{*}{ Aetorache } & & A1 \\
& A & A2 \\
& B & B1 \\
\hline
\end{tabular}
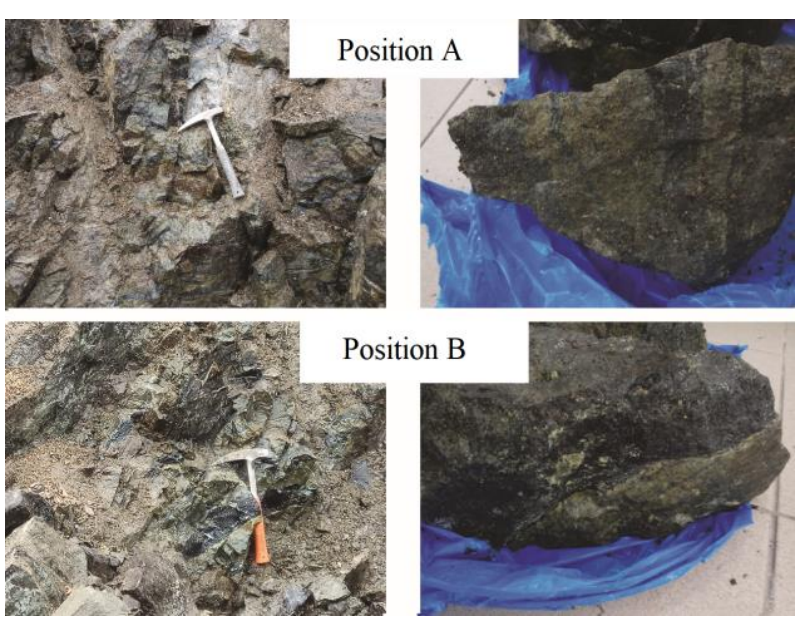

Figure 3. Photographs of the two sampling positions, where the four samples were collected

\subsection{Analytical methods}

X-Ray Diffraction (XRD) was carried out in order to identify the mineralogical phases which are present in the chromite samples. In order to conduct the XRD measurements, the chromite samples were mechanically crushed and sieved through a $45 \mu \mathrm{m}$ stainless steel sieve to obtain fine powder. XRD analysis was performed using a SIEMENS 5005 Diffractometer (Ni filtered, $\mathrm{Cu} K_{a 1}=1.54050 \AA$ ). The $2 \theta$ scan range varied from 2 to $65^{\circ}$. Phase identification and quantification were carried out by matching the acquired diffractograms with the EVA software, COD-AMCSD database. The phase identification and the XRD measurement procedure includes approximate instrumental error $2 \mathrm{wt} \%$, regarding the phase composition.

Morphological examination was conducted by means of Scanning Electron Microscopy (SEM), using a JEOL 6610LV. The elemental analysis was carried out using an X-Max 80 (Oxford Instruments) Energy Dispersive Spectroscopy (EDS) detector attached to the SEM. Images, ele- ments maps and spectra were obtained and analysed using AZtech-Nanoanalysis software. Prior to SEM observation all samples were coated with carbon to avoid charging under the electron beam.

Loss on Ignition (LOI) measurements were conducted using a LECO TGA701, in the low temperature range of $25-107^{\circ} \mathrm{C}$ with a heating rate of $6^{\circ} \mathrm{C} / \mathrm{min}$ in $\mathrm{N}_{2}$ atmosphere, while in the high temperature range of $107-950^{\circ} \mathrm{C}$ with a heating rate $43^{\circ} \mathrm{C} / \mathrm{min}$ and $\mathrm{O}_{2}$ atmosphere.

Thermogravimetric analyses (TG/DTG) were conducted using a LECO TGA701 device in the temperature range of 25 to $1000^{\circ} \mathrm{C}$ with a heating rate $10^{\circ} \mathrm{C} / \mathrm{min}$, under air atmosphere with a flow rate of $3 \mathrm{~L} / \mathrm{min}$.

All analytical methods and measurement, except XRD methodology, were conducted in the laboratory of Applied Geochemistry, Mineral Resources Engineering Department, at University of Western Macedonia, Greece.

\section{Results and discussion}

In Figure 4, the XRD patterns of the A1 (a) and A2 (b) samples are shown, while the characteristic peaks corresponding to the major crystallographic phases are indicated. Phase identification analysis on samples A1 and $\mathrm{A} 2$ has shown that chromite is found in two forms: magnesio-chromite $(\mathrm{Mg}, \mathrm{Fe})(\mathrm{Cr}, \mathrm{Al})_{2} \mathrm{O}_{4}$ and aluminian chromite $\mathrm{Fe}(\mathrm{Al}, \mathrm{Cr})_{2} \mathrm{O}_{4}$. Moreover, on these samples, forsterite $\left(\mathrm{Mg}_{2} \mathrm{SiO}_{4}\right)$ and clinochrysotile $\mathrm{Mg}_{3} \mathrm{Si}_{2} \mathrm{O}_{5}(\mathrm{OH})_{4}$ phases were detected.

In Figure 5, the XRD patterns of the B1 (a) and B2 (b) samples are presented, where the characteristic peaks corresponding to the major crystallographic phases are indicated. Phase identification analysis on samples B1 and B2 has shown that except the aforementioned crystallographic phases detected in $\mathrm{A} 1$ and $\mathrm{A} 2$ samples, pyroaurite $\mathrm{Mg}_{6} \mathrm{Fe}_{2} \mathrm{CO}_{3}(\mathrm{OH})_{16} \cdot 4 \mathrm{H}_{2} \mathrm{O}$ and clinochlore $\mathrm{Mg}_{5} \mathrm{Al}\left(\mathrm{Si}_{3} \mathrm{Al}\right) \mathrm{O}_{10}(\mathrm{OH})_{8}$ may also be present in these samples.

In Table 3, the major phase analysis results from the XRD measurements are summarized. In overall, XRD results interpretation indicates that all samples collected from the investigation site (Aetorache, North Vourinos) mainly contain magnesium and aluminium chromite ("aluminium picrochromite"), accompanied with forsterite minerals (magnesium containing olivine), serpentine and chlorite occurancies. 
(a)

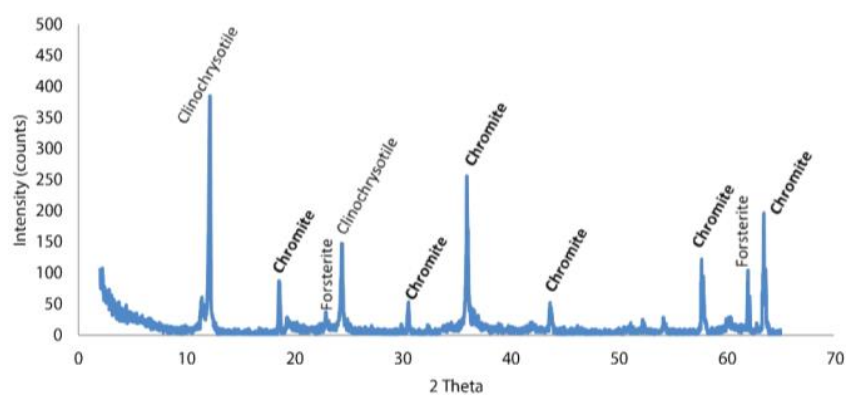

(b)

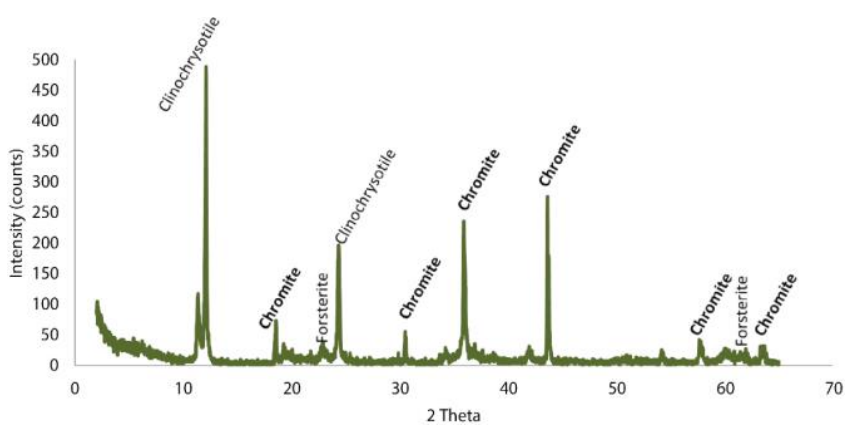

Figure 4. XRD patterns of samples A1 (a) and A2 (b)

(a)

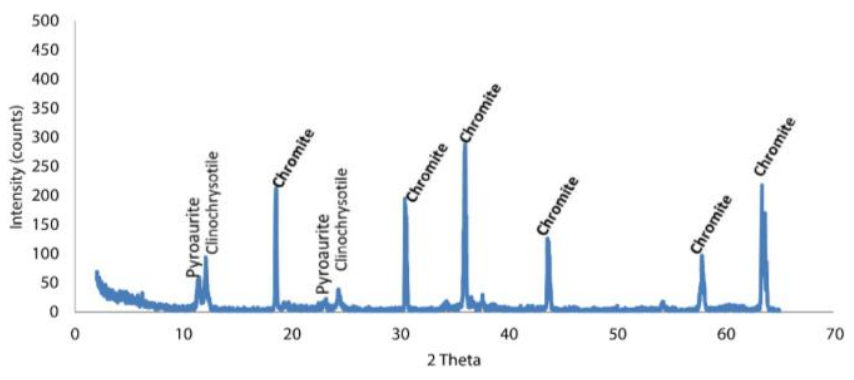

(b)

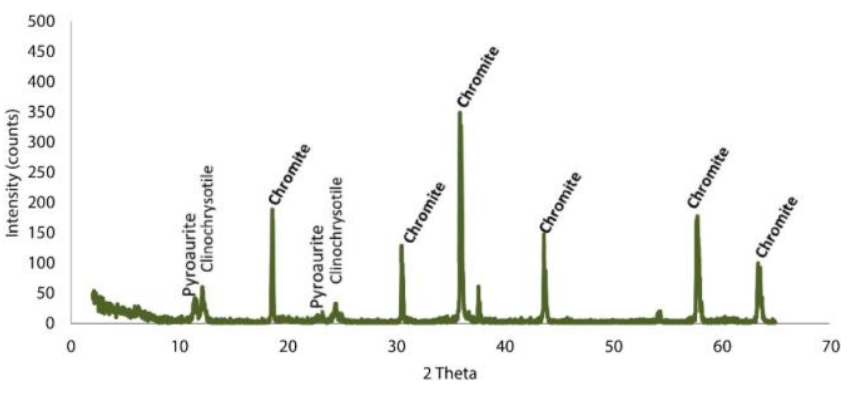

Figure 5. XRD patterns of samples B1 (a) and B2 (b)

Additionally, occupancies of the pseudo calcitehydrotalcite group (pyroaurite, stichtite) are observed. These minerals occur in dunite/diorite/harzburgite/peridotite assemblage as the main rocks of the ophiolite complex which hosts the chromite ore.

LOI (Loss of Ignition) measurement results are summarized in Table 4. According to these results, it is clear that samples with high amounts of minerals belonging to serpentine group and moderate amounts of chlorite group minerals and pyroaurite correspond to higher LOI values (11.04 to $12.96 \%$, on dry basis) likely at lower temperatures.
Table 3. Phase analysis results from the XRD

\begin{tabular}{lcccc}
\hline \multicolumn{1}{c}{$($ wt $\%)$} & $\begin{array}{c}\text { Sample } \\
\text { A1 }\end{array}$ & $\begin{array}{c}\text { Sample } \\
\text { A2 }\end{array}$ & $\begin{array}{c}\text { Sample } \\
\text { B1 }\end{array}$ & $\begin{array}{c}\text { Sample } \\
\text { B2 }\end{array}$ \\
\hline $\begin{array}{l}\text { Magnesiochromite } \\
(\mathrm{Mg}, \mathrm{Fe})(\mathrm{Cr}, \mathrm{Al})_{2} \mathrm{O}_{4}\end{array}$ & 23.99 & 22.17 & 50.57 & 50.53 \\
$\begin{array}{l}\mathrm{Aluminian} \text { chromite } \\
\mathrm{Fe}(\mathrm{Al}, \mathrm{Cr})_{2} \mathrm{O}_{4}\end{array}$ & 25.71 & 23.77 & 24.89 & 24.88 \\
$\begin{array}{l}\text { Forsterite, Syn } \\
\left(\mathrm{Mg}_{2} \mathrm{SiO}_{4}\right)\end{array}$ & 5.06 & 4.68 & 11.43 & 11.43 \\
$\mathrm{Clinochrysotile}_{\mathrm{Mg}_{3} \mathrm{Si}_{2} \mathrm{O}_{5}(\mathrm{OH})_{4}}$ & 45.24 & 49.37 & 0 & 0 \\
$\mathrm{Pyroaurite}_{\mathrm{Mg}_{6} \mathrm{Fe}_{2} \mathrm{CO}_{3}(\mathrm{OH})_{16} \cdot 4 \mathrm{H}_{2} \mathrm{O}}$ & 0 & 0 & 10.37 & 10.42 \\
$\mathrm{Clinochlore}$ & & & 2.74 & 2.74 \\
$\mathrm{Mg}_{5} \mathrm{Al}_{\left(\mathrm{Si}_{3} \mathrm{Al}\right) \mathrm{O}_{10}(\mathrm{OH})_{8}}$ & 0 & 0 & 2.74 \\
\hline
\end{tabular}

Table 4. Moisture and LOI measurements

\begin{tabular}{lccc}
\hline Sample ID & Moisture (\%) & LOI $(\%)$ & LOI (dry basis) $(\%)$ \\
\hline Sample A1 & 1.10 & 10.18 & 9.18 \\
Sample A2 & 1.56 & 12.43 & 11.04 \\
Sample B1 & 0.52 & 4.36 & 3.86 \\
Sample B2 & 1.63 & 14.38 & 12.96 \\
Sample & 0.44 & 4.65 & 4.23 \\
A1 + B1 & & & \\
\hline
\end{tabular}

On the other hand, samples with chromite dominated assemblages show lower values of LOI (3.86 to 4.23\%) probably at higher temperatures mainly due to the presence of minor hydrous and carbonaceous phases and the high resistance character of chromite to decompose at moderate temperatures.

Thermogravimetry (TG) and Differential Thermogravimetry (DTG) results for samples A1 (a), A2 (b) and B1 (a), B2 (b) are recorded below in Figures 6 and 7 respectively. Four main peaks are identified, which reflect four different temperature ranges, as follows:

$-40-120^{\circ} \mathrm{C}$, most likely referring to partial decomposition of pyraourite (belonging to hydrotalcite group);

$-170-230^{\circ} \mathrm{C}$, where a second split of pyraourite occurs;

$-370-420^{\circ} \mathrm{C}$, with the decomposition probably of chrysotile (kaolinite-serpentine group); and

$-650-720^{\circ} \mathrm{C}$, with partial cleavage of clinochlore (chlorite group).

The products of the above decomposition processes might likely correspond at low temperatures to volatile matter, and as temperature increases, several oxides and silicate phases are formed. The pattern for both TG and DTG curves are more or less the same for all samples examined. Specifically, the \% weight loss, for all samples, is varying between 4.4 and $14.36 \%$, in the temperature range 600 to $750^{\circ} \mathrm{C}$. In this temperature range, the decomposition of some hydrated siliceous minerals (e.g. serpentinite, chlorite) towards the formation of metal oxides is probably taking place. These results are relevant to LOI data mentioned above.

Results from SEM-EDS mapping of A1 sample are indicated in Figure 8. As it can be observed from the individual elemental maps in Figure 8c, there are two distinct microphase types: one with the major elements being $\mathrm{Cr}, \mathrm{Fe}$ and $\mathrm{Al}$, and a second one where the major elements are $\mathrm{Si}$ and $\mathrm{Mg}$. In order to shed light into the precise composition of each microphase type, several points in each distinct area were examined. 
(a)

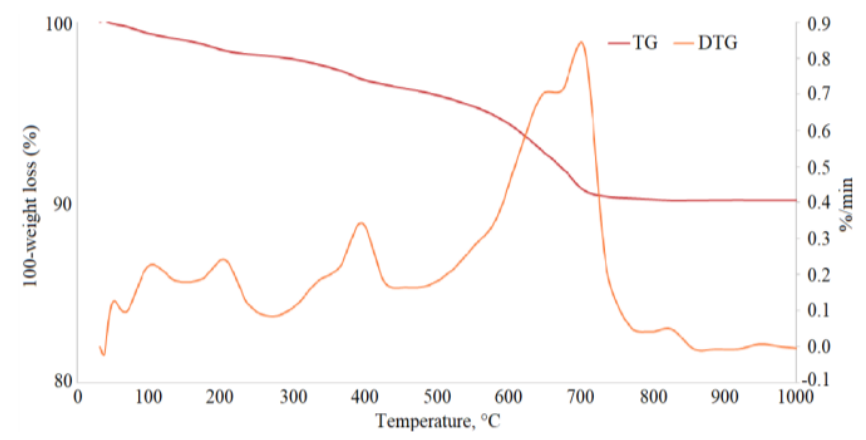

(b)

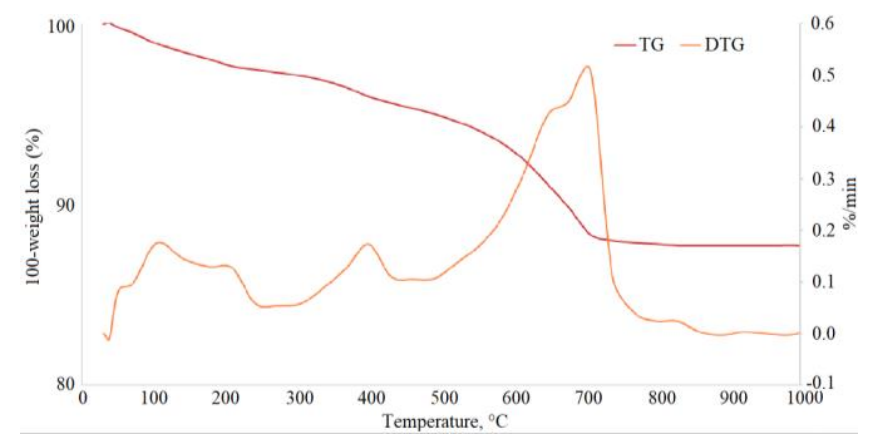

Figure 6. TGA and DTG curves for the A1 (a) and A2 (b) samples

(a)

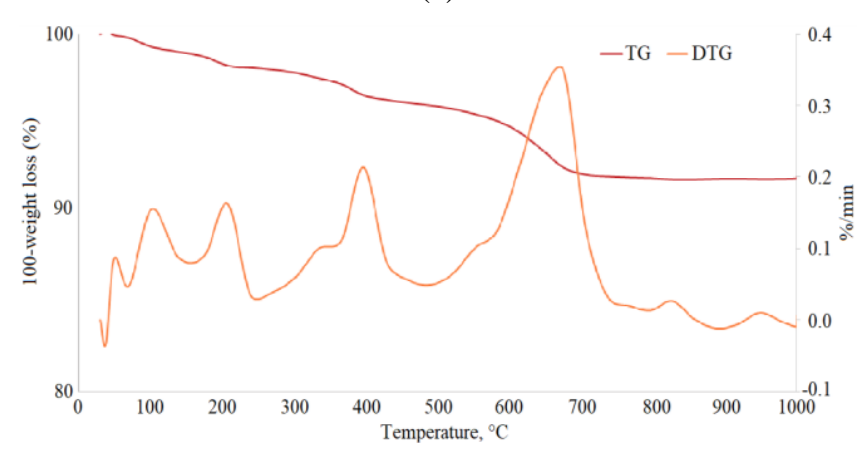

(b)

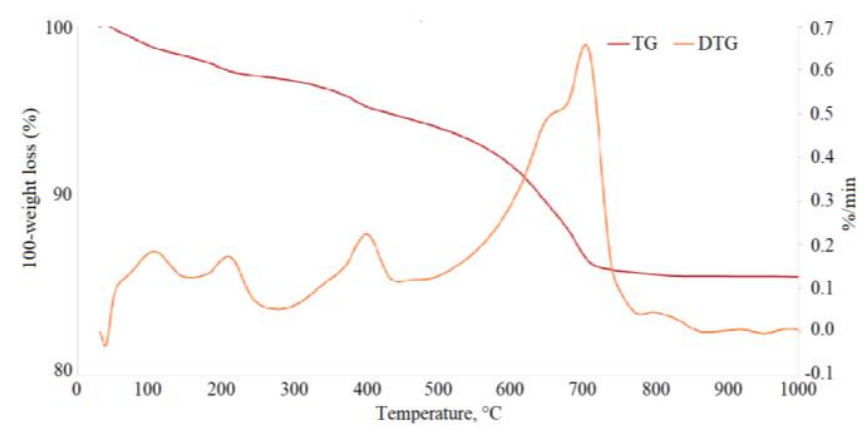

Figure 7. TGA and DTG curves for the B1 (a) and B2 (b) samples

In Figure 9, the point-by-point identification SEM-EDS image is presented, while Table 5 summarizes the elemental compositions of all samples and the individual points marked in Figure 9, expressed in both wt \% and at \%. Rather similar results were obtained from the corresponding SEM-EDS analysis conducted for B1 sample, as shown in Figures 10 and 11 and Table 6. (a)

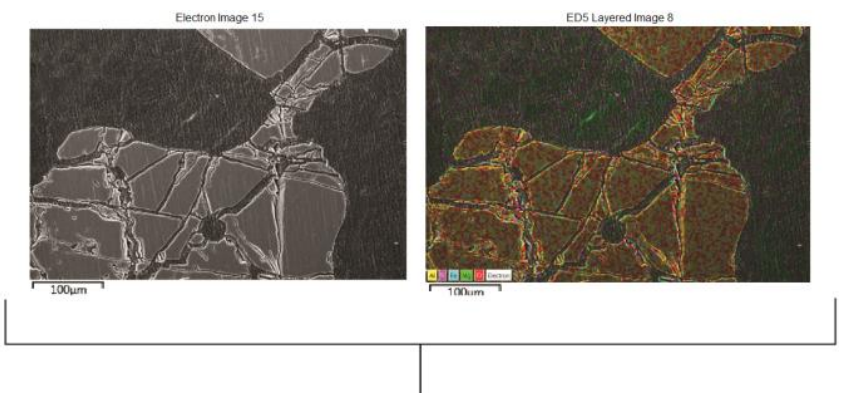

(c)

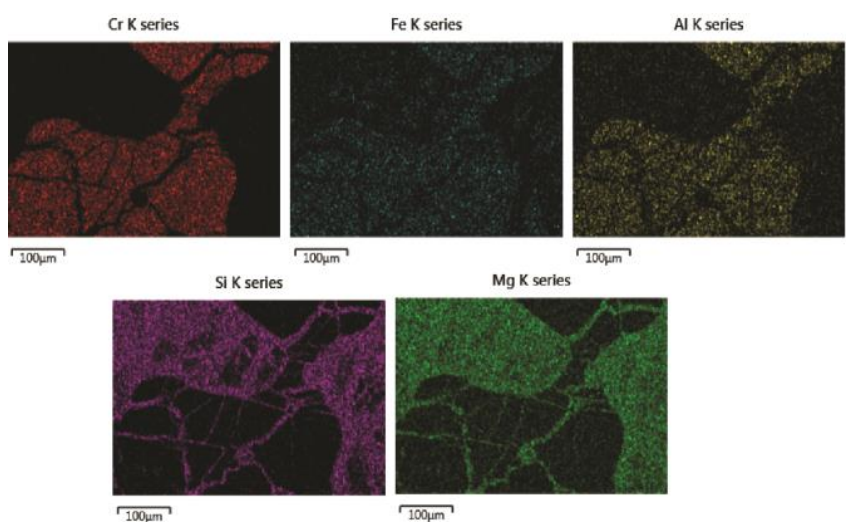

Figure 8. SEM-EDS maps from sample A1

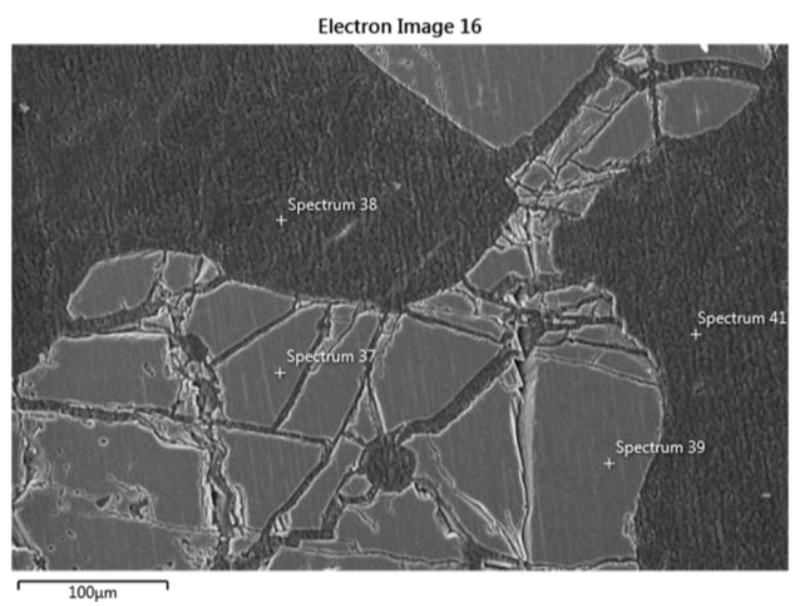

Figure 9. SEM image related to Point \& ID analysis from sample AI

As indicated from the SEM-EDS maps above, the main elements $\mathrm{Mg}$ and $\mathrm{Al}$ that are included in lattice are present in relatively high but varying amounts. However, basic ophiolitic constituents of a peridotite/dunite complex, such as magnesium olivine, serpentinite, ortho-pyroxenes and chlorites should be also present based on the elemental compositions recorded. In that sense, the SEM-EDS results shown above are in good accordance with literature findings [13], [14] and the XRD and TGA results presented here.

According to Grivas et al. [9] all exploitable chromian spinel deposits mined from the ' 50 s until the early ' 90 s are developed within a characteristic zone named as "metalliferous zone". Analytical results of this study (Tables 5 and 6) for all samples investigated indicate that the average ratio of $\mathrm{Cr} / \mathrm{Cr}+\mathrm{Al}$ varies between 0.77 and 0.78 , and that of $\mathrm{Mg} / \mathrm{Mg}+\mathrm{Fe}$ ranges from 0.56 to 0.59 . 
Table 5. Point \& ID results based on the SEM image of Figure 9

\begin{tabular}{|c|c|c|c|c|c|c|c|c|c|c|c|c|c|c|c|c|c|}
\hline \multirow{3}{*}{$\begin{array}{l}\text { Sample } \\
\text { name }\end{array}$} & \multirow{3}{*}{$\begin{array}{c}\text { Spectrum } \\
\text { No. }\end{array}$} & \multicolumn{8}{|c|}{ Elemental composition in wt $\%$} & \multicolumn{8}{|c|}{ Elemental composition in at $\%$} \\
\hline & & $\mathrm{Cr}$ & $\mathrm{Fe}$ & $\mathrm{Al}$ & $\mathrm{Mg}$ & $\mathrm{Si}$ & $\mathrm{O}$ & $\mathrm{Ni}$ & Mn & $\mathrm{Cr}$ & $\mathrm{Fe}$ & $\mathrm{Al}$ & $\mathrm{Mg}$ & $\mathrm{Si}$ & $\mathrm{O}$ & $\mathrm{Ni}$ & $\mathrm{Mn}$ \\
\hline & & \multicolumn{8}{|c|}{ wt $\%$} & \multicolumn{8}{|c|}{ at $\%$} \\
\hline A1 & 37 & 43.0 & 14.7 & 6.6 & 8.1 & - & 27.5 & - & - & 24.4 & 7.8 & 7.3 & 9.9 & - & 50.7 & - & - \\
\hline A1 & 38 & - & 3.1 & - & 28.6 & 21.5 & 46.7 & - & - & - & 1.1 & - & 23.9 & 15.6 & 59.4 & - & - \\
\hline A1 & 39 & 43.8 & 14.4 & 6.5 & 7.9 & - & 27.4 & - & - & 24.9 & 7.7 & 7.1 & 9.6 & - & 50.8 & - & - \\
\hline A1 & 41 & 0.4 & 16.5 & - & 28.5 & 6.4 & 48.1 & - & - & 0.2 & 6.3 & - & 24.9 & 4.8 & 63.8 & - & - \\
\hline
\end{tabular}

Table 6. Point \& ID results based on the SEM image of Figure 11

\begin{tabular}{|c|c|c|c|c|c|c|c|c|c|c|c|c|c|c|c|c|c|}
\hline \multirow[b]{2}{*}{$\begin{array}{l}\text { Sample } \\
\text { name }\end{array}$} & \multirow[b]{2}{*}{$\begin{array}{c}\text { Spectrum } \\
\text { No. }\end{array}$} & \multicolumn{8}{|c|}{ Elemental composition in wt $\%$} & \multicolumn{8}{|c|}{ Elemental composition in at $\%$} \\
\hline & & \multicolumn{7}{|c|}{ wt $\%$} & $\mathrm{Mn}$ & $\mathrm{Cr}$ & $\mathrm{Fe}$ & $\mathrm{Al}$ & $\begin{array}{r}\mathrm{Mg} \\
\mathrm{at}\end{array}$ & $\mathrm{Si}$ & $\mathrm{O}$ & $\mathrm{Ni}$ & $\mathrm{Mn}$ \\
\hline B1 & 32 & 44.8 & 12.5 & 6.8 & 7.9 & - & 27.9 & - & - & 25.3 & 6.6 & 7.4 & 9.5 & - & 51.2 & - & - \\
\hline B1 & 33 & - & 2.5 & - & 28.6 & 23.4 & 45.4 & - & - & - & 0.9 & - & 24.0 & 17.0 & 58.0 & - & - \\
\hline B1 & 34 & 44.6 & 13.3 & 6.6 & 8.0 & - & 27.5 & - & - & 25.3 & 7.0 & 7.3 & 9.7 & - & 50.7 & - & - \\
\hline $\mathrm{B} 1$ & 35 & - & 6.7 & - & 28.0 & 17.8 & 47.1 & 0.4 & - & - & 2.5 & - & 23.7 & 13.0 & 60.6 & 0.1 & - \\
\hline
\end{tabular}

(a)

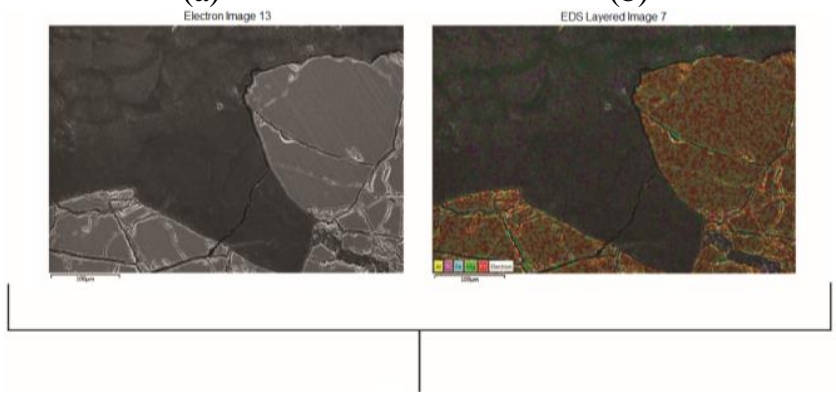

(c)
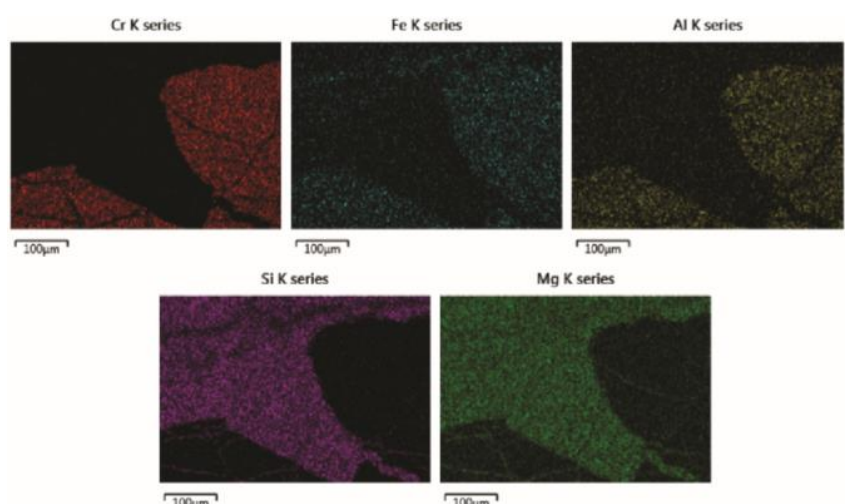

Figure 10. SEM-EDS maps from sample B1

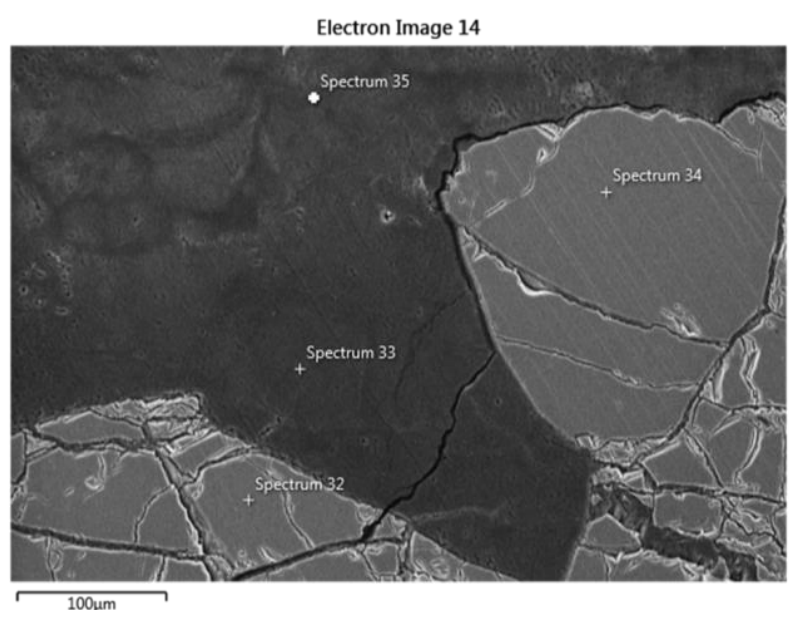

Figure 11. SEM image related to Point \& ID analysis from sample B1
These figures are very close to those reported by Kapsiotis [13] from the Voidolakos and Xerolivado mines, Vourinos ophiolite complex. Thus, these chromites could be classified as magnesium chromites in the solid solubility system, shown in the form of a simplified quadratic solid solutions chart in Figure 12.

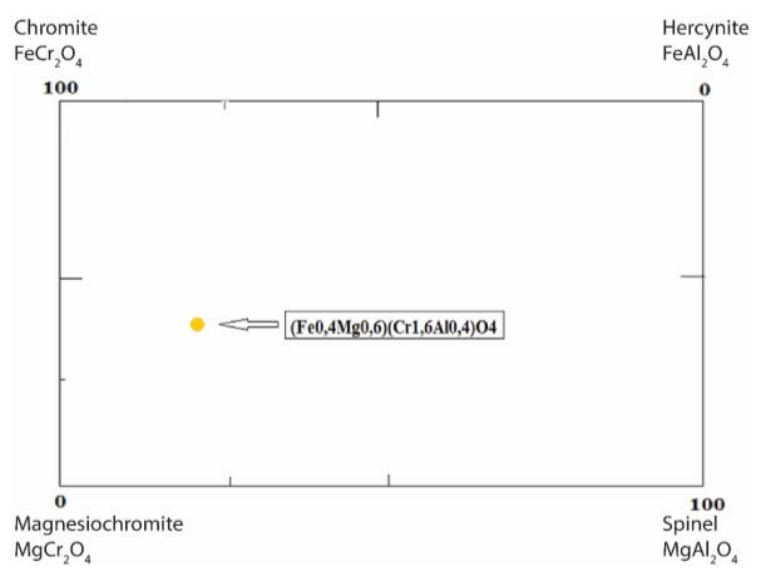

Figure 12. Quadratic Solid Solutions Series of chromite with the indication of computed average chemical formula of the magnesium chromite examined according to SEM-EDS results

Assuming the ideal magnesium chromite stoichiometry $\left(\mathrm{MgCr}_{2} \mathrm{O}_{4}\right)$, the divalent magnesium ion $\left(\mathrm{Mg}^{+2}\right)$, according to the SEM-EDS results (Tables 5 and 6) is partially replaced by the divalent ferrous ion $\left(\mathrm{Fe}^{+2}\right)$ by more than 40 at $\%$ in the solid solution series chromite-magnesium chromite $\left(\mathrm{Fe}_{0.4} \mathrm{Mg}_{0.6}\right)$. Simultaneously, a partial replacement of the trivalent chromium ion $\left(\mathrm{Cr}^{+3}\right)$ by the trivalent aluminum ion $\left(\mathrm{Al}^{+3}\right)$ by more than 20 at $\%$ also occurs. These chemical processes are indicative of a geochemical environment rich in magnesium and aluminum, possibly in aluminosilicates, such as serpentine, chlorite and tremolite. Apparently, there are several natural solubility solid-state geochemical systems with up to $100 \%$ substitution of chromite by magnesium chromite and vice versa $\left(\mathrm{Fe}^{+2} \leftrightarrow \mathrm{Mg}^{+2}\right)$ in tetrahedral positions of the lattice, magnesium chromite by spinel $\left(\mathrm{Cr}^{+3} \leftrightarrow \mathrm{Al}^{+3}\right)$ in octahedral positions, spinel by hercynite and hercynite by chromite. These successive substitutions are mainly due to the similarity of the ionic radii of the divalent and trivalent cations in- 
volved, in the tetrahedral and octahedral crystallographic sites respectively, but also to the actual formation conditions of temperature and pressure. It is worth noting that the average stoichiometric chromite formula for the SEM-EDS analysis result is $\left(\mathrm{Fe}_{0.4} \mathrm{Mg}_{0.6}\right)\left(\mathrm{Cr}_{1.6} \mathrm{Al}_{0.4}\right) \mathrm{O}_{4}$ (Fig. 12). Moreover, according to the SEM-EDS Point \& ID analysis results of the $\mathrm{A} 1$ and $\mathrm{B} 1$ chromite samples (Tables 5 and 6), $\mathrm{Cr} / \mathrm{Fe}$ ratios reveal mean values 3.18 and 3.73 for sample A1 and sample B1 respectively. In accordance with relevant literature findings [6], [12], these values underline the considerable presence of metallurgical type of chromite.

\section{Conclusions}

XRD results indicate that all the samples in the research area (Aetorachi, South Vourinos) contain mainly magnesiumand aluminum- chromite ("aluminum-picrochromite") along with forsterite (magnisian olivine), serpentine and chlorite occurrences; also, occurrences of the hydrotalcite group (pyroaurite/stichtite). These minerals appear in the dunite/diorite/harzburgite/ peridotite association as the main components of the ophiolitic complex that host the chromite ore.

The above results are also confirmed by semi-quantitative elemental analyses using SEM-EDS: from the chemical elements that are present in chromite, chromium is present in all samples in relatively high amounts, along with variable magnesium, aluminum and iron amounts. The indicative average chemical formula of this specific chromite type is calculated to be: $\left(\mathrm{Fe}_{0.4} \mathrm{Mg}_{0.6}\right)\left(\mathrm{Cr}_{1.6} \mathrm{Al}_{0.4}\right) \mathrm{O}_{4}$. It is worth noting that, since the $\mathrm{Cr} / \mathrm{Fe}$ ratio is higher than $2.8 / 1$, the chromite of the Aetorache sampling area can be classified as metallurgical chromite.

The LOI of the samples with higher content of chlorite/serpentine/tremolite/pyroaurites paragenetic accessory minerals in the chromite deposits is comparatively much higher at relatively low temperatures (11.04 and 12.96\%) than the samples where the chromite predominates quantitatively (3.86 and 4.23\%) with lower volatile phase contents (hydrates and carbonates).

The TG/DTG results indicated weight losses in the range of 4.4 to $14.36 \%$, at temperatures between 600 and $750^{\circ} \mathrm{C}$, where the decomposition of some hydroxyl-rich silicate minerals (serpentinite, chlorite) occurs, followed by formation of metal oxides. These findings are quite comparable to LOI $(\%)$ results.

The results of the current research can be useful for the ongoing and future exploitation of chromite ore in the Vourinos complex, which is situated in Region of Western Macedonia, Greece, an area with high unemployment and rather slow economic growth.

\section{Acknowledgements}

The authors would like to thank the Specific-Account Research Committee (ELKE) of University of Western Macedonia, Greece for financing the research work presented here under the research grant "Geochemical characterization and evaluation of chromite ore from mount Vourinos of Grevena and Kozani" (DecisionNo. 8/2019 51.1-51.3). Moreover, the contribution of Agapi Vasiliadou ( $\mathrm{PhD}$ candidate) and Prof. Andreas Iordanidis of the Department of Mineral Resources Engineering, University of Western Macedonia, Greece for the LOI and thermogravimetry measurements is gratefully acknowledged. Finally, the authors would like to thank Dr. Charalampos Vasilatos of the Department of Geology and Geo-environment, at the National and Kapodistrian University of Athens, Greece for the XRD analyses.

\section{References}

[1] Dick, H.J.B., \& Bullen, T. (1984). Chromian spinel as a petrogenetic indicator in abyssal and alpine-type peridotites and spatially associated lavas. Contributions to Mineralogy and Petrology, 86(1), 54-76. https://doi.org/10.1007/BF00373711

[2] Economou-Eliopoulos, M. (1996). Platinum-group element distribution in chromite ores from ophiolite complexes: implications for their exploration. Ore Geology Reviews, 11(6), 363-381. https://doi.org/10.1016/S0169-1368(96)00008-X

[3] Konstantopoulou, G., \& Economou-Eliopoulos, M. (1991). Distribution of platinum-group elements and gold within the Vourinos chromitite ores, Greece. Economic Geology, 86(8), 1672-1682. https://doi.org/10.2113/gsecongeo.86.8.1672

[4] Bacuta, G.C., Kay, R.W., Gibbs, A.K., \& Lipin, B.R. (1990). Platinumgroup element abundance and distribution in chromite deposits of the Acoje Block, Zambales Ophiolite Complex, Philippines. Journal of Geochemical Exploration, 37(1), 113-145. https://doi.org/10.1016/03756742(90)90086-P

[5] Cina, A., Caselli, H., \& Goci, L. (1986). Chromites in the ophiolites of Albanides. Metallogeny of Ophiolites, 107-128.

[6] Economou, M., Dimou, E., Economou, G., Migiros, G., Vacondios, I., Grivas, E., \& Dabitzias, S. (1986). Chromites: UNESCO's IGCP-197 Project, Metallogeny of Ophiolites. Theophrastus Publications.

[7] Zhou, M.F., \& Robinson, P.T. (1997). Origin and tectonic environment of podiform chromite deposits. Economic Geology, 92(2), 259-262. https://doi.org/10.2113/gsecongeo.92.2.259

[8] Tindle, A.G., \& Pearce, J.A. (1983). Assimilation and partial melting of continental crust: evidence from the mineralogy and geochemistry of autoliths and xenoliths. LITHOS, 16(3), 185-202. https://doi.org/10.1016/0024-4937(83)90023-3

[9] Grivas, E., Rassios, A., Konstantopoulou, G., Vacondios, I., \& Vrahatis, G. (1993). Scientific communications: Drilling for "blind" podiform chrome orebodies at voidolakkos in the vourinos ophiolite complex, Greece. Economic Geology, 88(2), 461-468. https://doi.org/10.2113/gsecongeo.88.2.461

[10] Economou-Eliopoulos, M., \& Vacondios, I. (1995). Geochemistry of chromitites and host rocks from the Pindos ophiolite complex, northwestern Greece. Chemical Geology, 122(1-4), 99-108. https://doi.org/10.1016/0009-2541(94)00154-Z

[11] Rassios, A.E. (2004). A geologist's guide to West Macedonia. Grevena, Greece: The Grevena Development Agency, 119 p.

[12] Rassios, A., Smith, A., \& Kostopoulos, D. (2009). Ophiolites 2008 Guidebook: Link between the Mesohellenic Ophiolites and the Pelagonian Margin. Journal of the Virtual Explorer, (34), 1. https://doi.org/10.3809/jvirtex.2009.00213

[13] Kapsiotis, A.N. (2015). Alteration of chromitites from the Voidolakkos and Xerolivado mines, Vourinos ophiolite complex, Greece: Implications for deformation-induced metamorphism. Geological Journal, 50(6), 739-763. https://doi.org/10.1002/gj.2590

[14] Tzamos, E., Filippidis, A., Michailidis, K., Koroneos, A., Rassios, A., Grieco, G., Pedrotti, M., \& Stamoulis, K. (2016). Mineral chemistry and formation of awaruite and heazlewoodite in the xerolivado chrome mine, Vourinos, Greece. Bulletin of the Geological Society of Greece, 50(4), 2047-2056. https://doi.org/10.12681/bgsg.11951

\section{Мінералогічна характеристика та оцінка хромітової руди в масиві Гревена та Козані Вурінос, Західна Македонія, Греція}
А. Баклаварідіс, К. Ваталіс, В. Караянніс, П.-Н. Бенетіс, Г. Харалампідес
Мета. Дослідження зразків хромітової руди з рудника “Еторачес" в південній частині масиву Вурінос у Західній Македонії, Греція, з мінералого-геохімічної точки зору для оцінки можливості його промислової розробки. 
Методика. Були проведені рентгеноструктурний аналіз мінеральної фази (РФА), елементна скануюча електронна мікроскопія у поєднанні з аналізом енергодисперсійної спектроскопії (СЕМ-ЕДС) та термогравіметрія/диференціальна термогравіметрія (ТГ/ДТГ).

Результати. Результати РФА показали, що всі зразки містять в основному фази хроміту магнію та алюмінію (“пікрохроміт алюмінію"), а також прояви форстериту (магнезіального олівіну), серпентину й хлориту. Отримано середню хімічну формулу на основі результатів СЕМ-ЕДС, яка вказує на конкретний тип хроміта: $\left(\mathrm{Fe}_{0.4} \mathrm{Mg}_{0.6}\right)\left(\mathrm{Cr}_{1.6} \mathrm{Al}_{0.4}\right) \mathrm{O}_{4}$. Встановлено, що втрати маси ТГ/ДТГ, виявлені в діапазоні від 4.4 до 14.36\%, при температурах від 600 до $750^{\circ} \mathrm{C}$, вказують на присутність силікатних мінералів, багатих гідроксилом, серпентиніту і хлориту. Мінеральні фази, виявлені в даному аналізі, присутні в основних породах дуніт/діорит/гарцбургіт/перидотит офіолітового комплексу, що вміщує хромітові руди.

Наукова новизна. Надана оцінка геохімічних аспектів хромітового масиву Вурінос, регіон Західної Македонії, Греція, особливо легкодоступних та експлуатованих хромітових родовищ рудником "Еторачес" на основі елементного, фазового та термічного аналізів.

Практична значимість. Хромітовий мінерал, особливо металургійний, має велике значення в металургійній промисловості. У цьому сенсі результати даного дослідження чистоти хроміту і мінеральної структури є передумовою для майбутньої експлуатації хромітового родовища рудника Еторачес, зокрема, і в цілому для триваючої розробки хромітової руди в масиві Вурінос. Греція регіон з високим рівнем безробіття й досить повільним економічним зростанням.

Ключові слова: хромітова руда, масив Вурінос, рудник Еторачес, мінералогічна характеристика, геохімія, РФА, СЕМ-ЕДС, ТГ/ДТГ

\section{Минералогическая характеристика и оценка хромитовой руды в массиве Гревена и Козани Вуринос, Западная Македония, Греция}

\section{А. Баклаваридис, К. Ваталис, В. Караяннис, П.-Н. Бенетис, Г. Харалампидес}

Цель. Исследование образцов хромитовой руды из рудника “Эторачес” в южной части массива Вуринос в Западной Македонии, Греция, с минералого-геохимической точки зрения для оценки возможности его промышленной разработки.

Методика. Были проведены рентгеноструктурный анализ минеральной фазы (РФА), элементная сканирующая электронная микроскопия в сочетании с анализом энергодисперсионной спектроскопии (СЭМ-ЭДС) и термогравиметрия/дифференциальная термогравиметрия (ТГ/ДТГ).

Результаты. Результаты РФА показали, что все образцы содержат в основном фазы хромита магния и алюминия (“пикрохромит алюминия”), а также проявления форстерита (магнезиального оливина), серпентина и хлорита. Получена средняя химическая формула на основе результатов СЭМ-ЭДС, указывающая на конкретный тип хромита: $\left(\mathrm{Fe}_{0.4} \mathrm{Mg}_{0.6}\right)\left(\mathrm{Cr}_{1.6} \mathrm{Al}_{0.4}\right) \mathrm{O}_{4}$. Установлено, что потери массы ТГ/ДТГ, обнаруженные в диапазоне от 4.4 до $14.36 \%$, при температурах от 600 до $750^{\circ} \mathrm{C}$, указывают на присутствие силикатных минералов, богатых гидроксилом, серпентинита и хлорита. Минеральные фазы, обнаруженные в настоящем анализе, присутствуют в основных породах дунит/диорит/гарцбургит/перидотит офиолитового комплекса, вмещающего хромитовые руды.

Научная новизна. Дана оценка геохимических аспектов хромитового массива Вуринос, регион Западной Македонии, Греция, особенно легкодоступных и эксплуатируемых хромитовых месторождений рудником “Эторачес” на основе элементного, фазового и термического анализов.

Практическая значимость. Хромитовый минерал, особенно металлургический, имеет большое значение в металлургической промышленности. В этом смысле результаты настоящего исследования чистоты хромита и минеральной структуры являются предпосылкой для будущей эксплуатации хромитового месторождения Эторачес, в частности, и в целом для продолжающейся разработки хромитовой руды в массиве Вуринос. Греция - регион с высоким уровнем безработицы и довольно медленным экономическим ростом.

Ключевые слова: хромитовая руда, массив Вуринос, рудник Эторачес, минералогическая характеристика, геохимия, РФА, СЭМ-ЭДС, ТГ/ДТГ 